\title{
FACTORS WHICH INFLUENCE SUSTAINABLE IMPLEMENTATION OF CORPORATE GOVERNANCE SYSTEMS IN AN INSTITUTION OF HIGHER LEARNING
}

\author{
T. E. B. Assan
}

Faculty of Education

North West University, Mafikeng Campus

Mafikeng, South Africa

e-mail: thomas.assan@nwu.ac.za / https://orcid.org/0000-0003-1325-4264

\section{ABSTRACT}

As the demand for higher education continues to grow and as governments acknowledge their role in promoting economic development, it becomes increasingly important to ensure that higher education systems are managed in an effective way. The study examined the factors which influence effective and sustainable corporate governance in a merged University. The study was intended to create awareness of the challenges and opportunities regarding perceived conflicts in a new institution of Higher Learning with respect to management of transformation in higher education A mixed method approach was used and, as a result, data were collected using a questionnaire and interview instruments. The sample was made up of 120 randomly selected staff and students. The research established that issues of language and culture, effective communication as well as stakeholders' consultations among others are factors which influence effective corporate governance. The study recommended that more should be done to improve the culture, ethos and the practices that would enhance a sustainable corporate governance system.

Keywords: corporate governance, economic development, higher education, merger, stakeholders

\section{INTRODUCTION AND BACKGROUND}

The Department of Higher Education and Training (DHET), along with the representative body, the Higher Education South Africa (HESA), now Universities South Africa (USAF) have indicated that South Africa has reached a critical juncture in the governance of higher education, a belated moment of truth - even if it's precise nature remains to be clarified. On reflection, it would appear that facing up to this moment of truth should not, as USAF's initial responses assumed, involve anachronistic attempts to revive the notion of "institutional autonomy" once again. Rather, it raises the question whether or not the foundational commitment to "cooperative governance" of higher education still has relevance in a post-apartheid, democratic South Africa (Du Toit 2014, 1; Tricker, and Tricker 2015, 276). 
In the late 2012, Parliament passed the Higher Education and Training Laws Amendment Act, significantly extending the powers of the Minister to intervene in the affairs not only of "failing" universities unable to deal with their own crises of governance and financial management, but also making it applicable across the sector to other institutions of higher education (Republic of South Africa 2012, 6).

Higher education systems are getting more complex due to the growth in the number of public and private institutions, so that the task of managing and monitoring the sector is becoming more specialised and demanding in terms of financial policies that are currently in place. These may be the result of ineffective corporate governance within the institutions of higher learning, which is basically affected by the governing body's characteristics, their principles, policies and their activities. The study investigated the sustainability of the current corporate governance structures of a merged higher education institution in South Africa in light of its transformation debacle relating to council and management composition in terms of culture, race and equity. The study specifically focuses on Campus A which formed part of the merged institution of higher learning. In this regard the study investigated the factors which influence sustainable implementation of corporate governance systems in an institution of Higher Learning.

\section{STATEMENT OF THE PROBLEM}

The main purpose of this study is to examine the factors that promote sustainability of governance in institutions of higher learning. Currently universities are considered as income generating ventures and they are expected to run as business entities. Good corporate governance has meant that universities should have all the business functional areas running effectively and efficiently. These include the general management, human resource, finance, marketing and public relations, to mention but a few (Bricall, and Roversi-Monaco 2008, 18; Rodriguez-Fernandez 2016, 140). The key research question in this study is: what are the factors which influence sustainable implementation of corporate governance systems in an institution of Higher Learning?

\section{AGENCY THEORY FOR CORPORATE GOVERNANCE}

With the understanding that theory refers to a system of ideas which are interconnected and condensed together to organise knowledge about the world (Neuman 2006, 24), for the purpose of this study, agency theory is considered to best define the concept of corporate governance. Agency theory as an idea is best attributed to Coase $(1995,40)$. No matter the intensive nature of the theory, the ideals have only been applied to directors and boards since the 1980's. The 
theory considers that people self-interested and not altruistic. Therefore, they cannot be trusted to act in the best interests of others. On the other side, the key to what people desire is ensure that their utility is maximize. By implication agency theory establishes a contract to include the relationship between directors and shareholders (Adams 2002, 55; Shi, Connell, and Hoskisson 2017, 1270).

Agency theory establishes that for the simple fact that professional managers have repositories of superior information, they gained advantage over the very owners of the firms. It is hoped that at one stage, interest on personal welfare will not be in the minds of firms' top managers. In the light of sure possibilities, agency theory speaks to interest of top managers being shifted to the welfare of the firm's shareholders (Berle, and Means 1932, 8).

\section{DEVELOPMENT OF THE CONCEPT OF CORPORATE GOVERNANCE}

The concept of corporate governance is a practice that has been around for centuries. Despite the long standing history of this concept, the economies of African countries only started given attention to the principles of good governance in the beginning of the 1980s. Elahi $(2009,1172)$ affirm that the concept good governance was mentioned for the very first time in the 1989 World Bank report on Sub-Saharan Africa. Since this inception, many donor agencies in the1990s have sought the quest for good governance. Recently, the concept corporate governance has become a catchphrase in the world of business.

According to Solomon and Solomon $(2006,571)$, the understanding and use of the concept corporate governance have developed tremendously in many developing countries in Africa. Despite the wide use of the concept in Africa, it is still argued that corporate governance is not necessarily the answer to the plight of the developing economies in Africa (Rwegasira 2000, 264). This stand is defended by the fact that many African countries experience a lot of problems that affect successful implementation of corporate governance. The numerous everyday problems of low per capital incomes, disease and unstable political regimes require more intricate answers and not purely reliance on corporate governance concepts. To cast more doubts on the dependence on corporate governance in Africa, Okeahalam $(2004,363)$ and Tshipa et al. $(2018,26)$ hold that very little research has been conducted on corporate governance in the African continent and developing countries generally. As such, there is very little information to defend its success or failure. For a very long time in the African continent, the idea of corporate governance was never attended to. This lack of attention is considered as the driving factor for the lack of research in corporate governance. In the past, nobody ever questioned the ability of managers to run the organisation (Yakasai 2001, 247). As a result, there was little concern for corporate governance or the disclosure of information and issues 
transparency. Nowadays, that is no longer the situation. The concept corporate governance is presently known to be pivotal in the management of organizations in developing economies. As such, Tsamenyi, Enninful-Adu, and Onumah (2007, 330) and Asiedu et al. $(2020,1089)$ believe that since developing countries are often challenged with problems of weak legal controls, uncertain economies, frequent government intervention and protection of investors, it becomes even more necessary for them to adopt effective corporate governance structures.

\section{CORPORATE GOVERNANCE PRACTICES OF PUBLIC SECTOR ORGANIZATIONS}

To effectively and efficiently manage a public sector organization (especially an institution of learning) is problematic and of great concern in many countries. Since public sector organizations are increasingly being held more accountable for their performance, they are therefore expected to operate efficiently and effectively (Melese, Blandin, and OKeefe 2004, 104; Chinamal 2019, 1). By implication, public organisations have to do everything possible to improve on how their activities are undertaken. A common approach to improve these activities is through the use of performance contracts. However, activity based management practices too can lead to improved transparency and efficiency when conducting government activities. This also assists public sector organizations to accomplish their goals (Baird 2007, 563).

In the past, most public sector enterprises and institutions of learning especially in developing countries were established to offer employment opportunities for large numbers of people. This has changed tremendously in recent times. The management of public sector organisations nowadays is increasingly focused on results and customers (Jarrar and Schiuma 2007, 5; Chinamal 2019, 1). The reason for this shift attributed partly to a growing lack of interest by many communities and governments to hold on to a historical commitment simply because it's historic. In some countries, there are evidence of diminishing differences between the private and public sectors. In some cases, nowadays, more social responsibilities measures are at the forefront of private sector organizations. Whereas public sectors are now expected to focus on customers and defend their existence, the modern business community dedicate great effort to measurement, target, accountability, and productivity gains (Chinamal 2019, 2). There is further focus on the continued relevance and value of define programs. As such, an issue of great concern in both developed and developing countries is the proper management of public sector organizations.

In responding to the features and processes of political and managerial responses to transformation pressures, two distinct but related approaches to transformative leadership are described. The first approach is often referred to as reformed collegialism. This approach starts 
from the premise that at the centre of the transformation of the institution lays the intellectual agenda of higher education, which is non-negotiable. Thus, part of the transformation agenda is to reclaim and reassert the centrality of the intellectual traditions of higher education institutions. The starting point of the institutional change strategy is to be sensitive to, and to work within, the confines and limits of the prevailing institutional culture, rather than going to war against it (Birnbaum 1992, 200; Lukyanova, Daneykin, and Daneikina 2015, 569). This can be achieved through remoulding the institution so that it is better able to respond and adapt to the new demands that it faces, while holding on to the central tenets of the academic tradition of the university, namely the pursuit of truth, disinterested enquiry, etc. In other words, the leadership challenge is about facilitating academic excellence by supporting, managing, nurturing, and inspiring one's academic colleagues. Collegialists would concur with Ramsden $(1998,350)$ that "deep at the heart of effective leadership is an understanding of how academics work".

\section{CORPORATE GOVERNANCE IN HIGHER EDUCATION SECTOR}

The connection between higher education, sustainable human development, science, and technology is highly recognised by the United Nations Educational, Scientific, and Cultural Organization (UNESCO). In acknowledging the recognition, UNESCO has made higher education one of its top priorities (Elahi 2009, 1171). However, education in general and higher education specifically is not a sole means to development but only one of the many outlets to the development process of a country (Van den Bor, and Shute 1991, 9). As such, it is necessary for institutions of higher education to be effectively governed as they are of prime significance in a country's development (Fourie 1999, 278). This study investigated the perception of staff on corporate governance system in a selected campus of one of the merged universities in South Africa.

In the higher education sector of South Africa, the wide ideologies of corporate governance are practically expressed through the discrete duties of two traditional bodies. These traditional bodies include the institution's Council and Senate; through a new body, the Institutional Forum; and through the interrelationship of these three governance agencies (Republic of South Africa 1997, 6). The roles of these bodies are buttressed by the dual principles of institutional autonomy and academic freedom. Thus, the Higher Education Act states that:

"it is desirable for higher education institutions to enjoy freedom and autonomy in their relationship with the State within the context of public accountability and the national need for advanced skills and scientific knowledge." 
Academic freedom as implied the dual principle is declared in the 1997 White Paper as:

"the absence of outside interference, censure or obstacles in the pursuit and practice of academic work. It is a precondition for critical, experimental and creative thought and therefore for the advancement of intellectual inquiry and knowledge. Academic freedom and scientific inquiry are fundamental rights protected by the Constitution."

Given that public higher education institutions in South Africa are more of teaching institutions, words of agreement between senate and council have huge implications (DBET 2011, 6). Considering that the budgets of higher education institutions are largely determined by student fee revenues and state subsidies, their reputations and ultimately ability to attract students depend on the threshold requirements for specific programmes of study. The same applies to the curricula and the effectiveness of assessment and examination systems in reflecting what students have learned. According to $\operatorname{DBET}(2011,8)$ these are broad and complicated that needs thoughtful processes. As such Councils will find it difficult to govern successfully without the corporation of Senates. The other purpose of corporative governance which include, ensuring that decision-making is participatory and transparent, the outcome has not been even. In many institutions of higher education, the new governance structures took the front seat in key institutional processes and decisions (Roberts 2006, 1). One of the most notably decision in which the new governance structure was instrumental is the appointment of vice-chancellors and other senior managers of the institution. Without undermining the changes made in the representation of stakeholders within governance structures, there is not much evidence to confirm to ultimate change in the way these structures function. More empirical is still needed in this area. However, it is obvious that some stakeholder representatives lack a clear idea of their role within governance structures (Hall, Symes, and Luescher 2002, 15).

While acknowledging the importance of the new, participatory governance principles, the other approach, referred to as "transformative managerialism", is characteristic of leaders who put more emphasis on "driving" transformation from the centre (Du Toit 2014, 1). In some cases the challenge for the transformative managerialists is to transform the culture of the institution from an authoritarian to a more democratic one. In others it is to manage the academics more efficiently, in line with policy principles or market pressures. In order to push the transformation agenda through the institution, power is centralised, decentralised and recentralised. This is done by expanding the "top" leadership group to include executive deans and certain professionals, such as finance or human resource directors (Cheng 2016, 7). Key strategic decisions are taken by this group and the deans become the implementers at the faculty 
level. Traditionally, the deans are supposed to represent and defend faculty interests. Whilst the executive dean and his/her faculty may have an autonomous budget and control over the appointment of new colleagues, the budget parameters and employment equity targets are set centrally.

\section{SUSTAINABILITY IN THE TRANSFORMATIONAL PROCESS IN HIGHER EDUCATION INSTITUTIONS}

Governance changes in South Africa have taken a number of different phases. Researching on institutional governance changes, Mohamed, and Cloete $(1996,6)$ and Dugan, and Taylor $(2016,86)$ identified three important phases of governance changes. The focus of the first phase was the request for formation of alternate democratic governance structures. A possible alternative is the establishment of the broad transformation forums. These forums are expected to contest the powers of the illicit and unrepresentative governance structures. This is peculiar of the then councils and senates. Change was expected to be achieved through overhauling the structure of council and senate so as to make sure that marginalised groups and communities were represented in institutional decision-making. The focus of the second phase was to ensure that institutional management structures were made legitimate. The best way envisaged to attain this was by replacing appointees of the apartheid era who were discredited in the university administrations. The discredited appointees were to be replaced with reformist institutional leaders who were democratically appointed (Dugan, and Taylor, 2016, 85). The idea of ensuring that the process of governance and decision-making be more accountable and participatory constituted the third phase. At university institutions which were mainly historically disadvantaged and some English-medium institutions, the process of phase three started before 1994. In other university institutions, the process started long after the ideologically laden agendas for democratic institutional governance that had come alive in the new legislation.

Leaders in higher education institutions are faced with particular challenges in the transformation process. These challenges stem from the very nature of the respective higher education institutions and are intertwined in it. This implies that the nature and structure of the higher education institutions and the values that underpin its institutional culture are not comfortably alongside the tune of its management. Researchers on higher education institutions Birnbaum (1992, 202) and Kogan $(2005,90)$ mention a number of the features and characteristics of institutions of higher education-universities that make them different from other kinds of organisations. These unique features to universities as institutions of higher education present a number of challenges to the exercise of effective leadership for three reasons: 
- The goals and objectives (teaching, research, community engagement and other services) of higher education institutions - universities are diverse and ambiguous. They are at times very highly contested and contradictory. This is different from private sector organisations. The diverse nature of these goals makes it problematic for leaders.

- Higher education institutions are very fragmented. Their fragmented nature gives rise to anarchistic organisational structures potentially. This very nature of this structure is described by Cheng $(2016,8)$ as university constitutes schools, semi-autonomous departments, and chairs. This makes faculties act like small sovereign states as they pursue their respective discipline specific and often self-interests. This pushes them at times to stand over and against the authority of the university as a unit.

- University systems have a decentralised nature of decision-making. This system of decision-making is organised around the production, preservation and dissemination of an intangible product called knowledge. As such, it gives rise to a highly fragmented authority structure which is focused on autonomous disciplinary units. In such situations, the loyalty of members is split between the organisation and the disciplinary networks and allegiances that transcend institutional boundaries (Kogan 2005, 90).

Another very essential challenge in managing change in universities is to resolve the field of tension between professional authorities that characterise the traditional universities (Tshipa et al. 2018, 30). At the centre of such tensions is a vice chancellor needed to maintain the core academic character and values of the institution. This study therefore focused on establishing the factors which influence sustainable implementation of corporate governance systems in an institution of Higher Learning.

\section{SIGNIFICANCE OF THE STUDY}

Firstly, a research of this nature adds to existing knowledge on the factors influencing sustained corporate governance in a new institution of higher Learning. Secondly, the study creates awareness of the challenges and opportunities regarding effective governance system in a new institution of Higher Learning with respect to management of transformation in higher education. Thirdly, the results of this study also provide information which policy makers in higher education ought to be aware of as they strive to provide a platform for policy formulation. Transformation in higher education has become a major issue of late and the results of this study shed light on factors which influence sustained corporate governance 
system institution of Higher Learning. On the whole the findings from this study are anticipated to stimulate further academic discourse.

\section{RESEARCH METHODOLOGY}

The study used survey design which is justified in the sense that the whole exercise involved collecting the respondents' opinions and perceptions (Fraenkel, and Wallen 2012, 218). The entire population of the study is made up of management and staff at one university campus. The target group therefore has a population of about 570 staff members. A sample of 150 respondents was earmarked to complete the questionnaire and out of this sample 10 per cent would be interviewed. However, due to the fees disturbances on the campus as a result of the arson attack and the consequent closure of the campus, 120 responses were received and 115 were deemed acceptable. Many of the data collection instruments that were distributed to staff in the administration block were burnt when the entire building was set alight. However, the response level was over 80 per cent which was deemed sufficient since the results of the study fit for the purpose and the reduced population meant the generalizability still existed from the reduced sample (Fraenkel, and Wallen 2012, 130).

Data was collected from management, members of senate and council as well as staff of from one particular institution in the form of questionnaire and interviews. In this study, a post positivism approach was applied in the sense that both quantitative and qualitative approaches formed the basis for data collection analysis and interpretation. According to O'Reilly, and Kiyimba $(2015,66)$ post-positivism attempts to rectify the challenges posed by positivism and hence bridge the divide between the two paradigms. The study used the quantitative paradigm to scientifically verify the responses at the same time the researchers intended to dig deep into the responses through interviews. The study used a combined approach to diminish the weaknesses of one and balanced it with the strengths of the other (Hasan 2016, 319).

A mixed method approach was adopted whereby a quantitative approach was supplemented with a qualitative method by way of interviews. This study adopted a mixed approach combining a quantitative and a qualitative method. The basis for adopting both qualitative and quantitative methodologies is explained better by Creswell $(2011,276)$ and Fraenkel, and Wallen $(2012,122)$ when they highlighted that a mixed method gives the researcher an added advantage in addressing adequately the research problem. They further point out that using one method only usually leaves space for incomplete responses and tend to make the researcher arrive at conclusions that do not cover the whole purpose of the study. Tables and graphs were also used to present the analysis. 


\section{RESULTS AND DISCUSSION}

The total number of questionnaires dispersed to respondents was 150 and 120 could be reached. All the questionnaires were administered to academic and support staff, including senate and council members as well as management of the campus. Of all the questionnaires distributed, 115 were completed and returned and 93 were usable which constitutes 81 per cent response rate. Through a semi-structure interviews an in-depth information was with 10 staff members, which ranged from Dean, Director, Professor, Senior lecturer, lecturer and administrative staff based on convenience sampling. A total of 10 staff forms a tenth of sample size for questionnaires. The interview process was to fill the gap and served as follow up from the closed ended and Likert style questions. The empirical qualitative information was based on experiences, attitudes and opinions of staff members at the Campus A. The results and discussions for the mixed methods are presented below.

Table 1: Response rate for the population

\begin{tabular}{|l|c|}
\hline Whole population for the study & 570 \\
\hline Lecturers, support staff, management available for the research & 150 \\
\hline Total respondents & 115 \\
\hline Non-response bias & 11 \\
\hline Useable responses & 93 \\
\hline Un-usable responses & 11 \\
\hline Useable response rate & $81 \%$ \\
\hline
\end{tabular}

Personal data of the respondents.

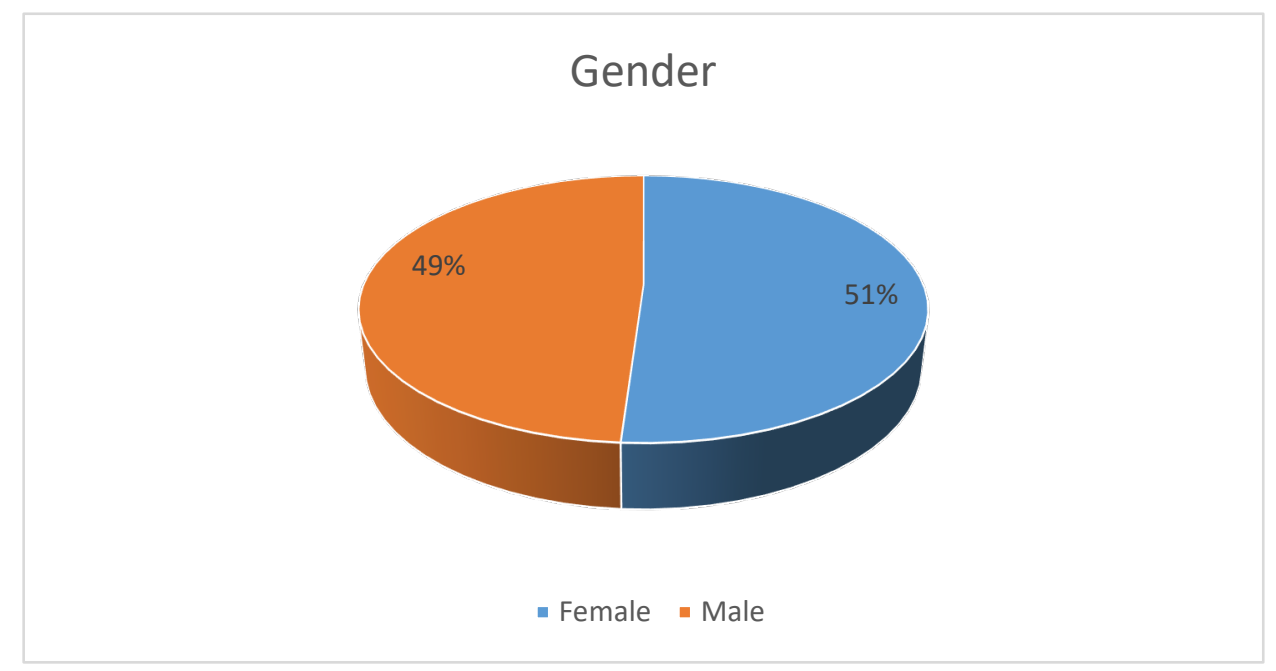

Figure 1: Gender

Figure 1 shows that the majority of the respondents were females with 51 per cent and the balance was made up of by males at 49 per cent. 
Table 2: Analysis of gender

\begin{tabular}{|l|c|c|}
\hline & $\chi^{\mathbf{2}}$ (Chi-square) & p-value \\
\hline I believe in the capability of the governance structure. & 11.300 & 0.023 \\
\hline The structure is responsive to the needs of all stakeholders. & 12.310 & 0.015 \\
\hline
\end{tabular}

The data reveals a statistically significant difference in gender of employee and the two statements asked to respondents. The gender of a respondent affects the manner in which a participant responded to the above statements at a significance level of 0.05 or 5 per cent.

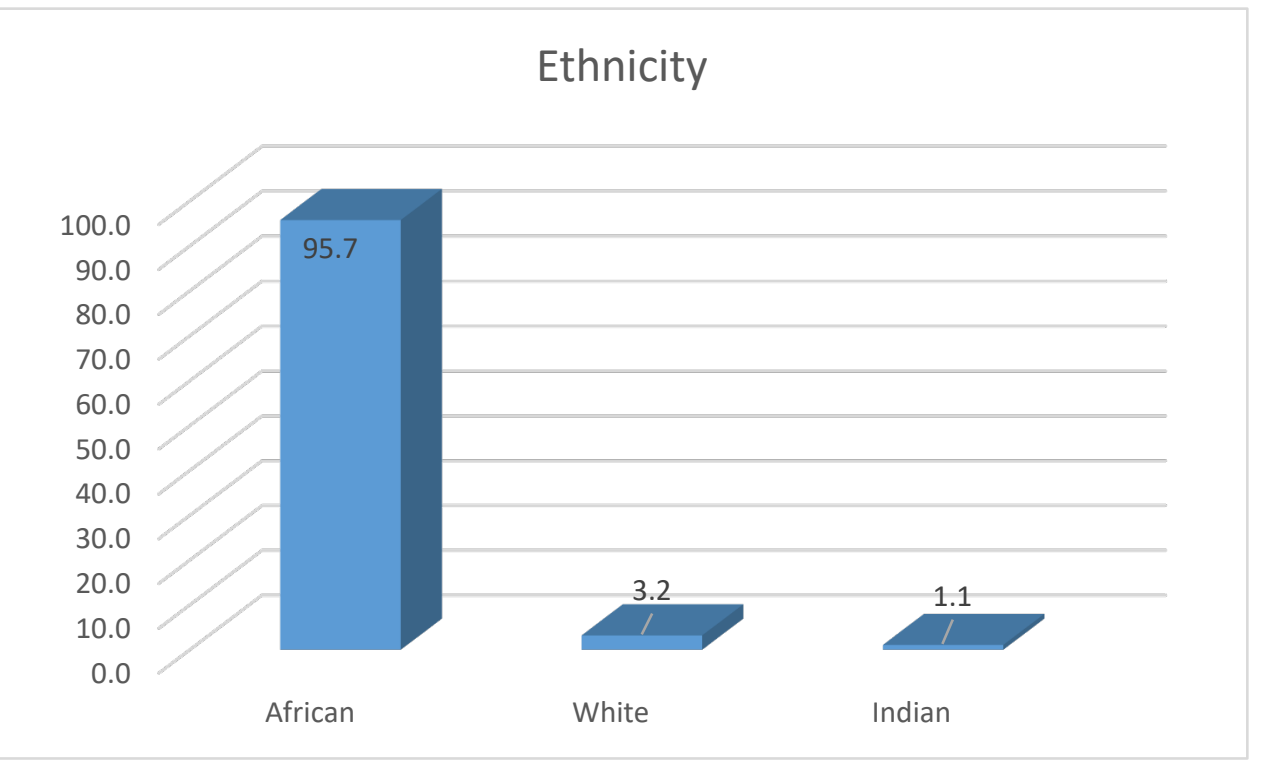

Figure 2: Ethnicity

Figure 2 shows that the majority (95.7\%) of the respondents are Africans, followed by 3.2 per cent of the White race and the Indians constituting the remaining 1.1 per cent.

This section presents the data from the questionnaire items based on the research questions.

Table 3: Ethnicity

\begin{tabular}{|l|c|c|}
\hline & $\chi^{2}$ (Chi-square) & p-value \\
\hline $\begin{array}{l}\text { Corporate governance will be effective if the current legislation } \\
\text { on higher education is revised? }\end{array}$ & 24.801 & 0.002 \\
\hline
\end{tabular}

The data shows a statistically significant difference in race and the one question asked to respondents. The race of a respondent affects the manner in which a research participant responded to the above question at a significance level of 0.05 or 5 per cent. 
Table 4: What do you consider as factors which influence sustainable corporate governance in your institution?

\begin{tabular}{|c|c|c|c|c|c|c|}
\hline \multirow[t]{2}{*}{ Statements } & Not sure & Agree & $\begin{array}{c}\text { Strongly } \\
\text { agree }\end{array}$ & Disagree & $\begin{array}{l}\text { Strongly } \\
\text { disagree }\end{array}$ & \multirow[t]{2}{*}{ Total } \\
\hline & 0 & 1 & 2 & 3 & 4 & \\
\hline $\begin{array}{l}\text { The language culture of the } \\
\text { institution is a hindrance to } \\
\text { effective governance. }\end{array}$ & $\begin{array}{c}9 \\
(15.3 \%)\end{array}$ & $\begin{array}{c}10 \\
(16.9 \%)\end{array}$ & $\begin{array}{c}19 \\
(32.2 \%)\end{array}$ & $\begin{array}{c}13 \\
(22.0 \%)\end{array}$ & $\begin{array}{c}8 \\
(13.6 \%)\end{array}$ & 59 (100) \\
\hline $\begin{array}{l}\text { I do not belief the current } \\
\text { governance system is well } \\
\text { sustained. }\end{array}$ & $\begin{array}{c}17 \\
(18.3 \%)\end{array}$ & $\begin{array}{c}19 \\
(20.4 \%)\end{array}$ & $\begin{array}{c}24 \\
(25.8 \%)\end{array}$ & $\begin{array}{c}15 \\
(16.1 \%)\end{array}$ & $\begin{array}{c}18 \\
(19.4 \%)\end{array}$ & $93(100)$ \\
\hline $\begin{array}{l}\text { I have confidence in the current } \\
\text { governance system of the } \\
\text { institution. }\end{array}$ & $\begin{array}{c}15 \\
(17.4 \%)\end{array}$ & $\begin{array}{c}17 \\
(19.8 \%)\end{array}$ & $\begin{array}{c}19 \\
(22.1 \%)\end{array}$ & $\begin{array}{c}18 \\
(20.9 \%)\end{array}$ & $\begin{array}{c}17 \\
(19.8 \%)\end{array}$ & $86(100)$ \\
\hline $\begin{array}{l}\text { I consider the corporate } \\
\text { governance system as pro- } \\
\text { active and very responsive. }\end{array}$ & $\begin{array}{c}17 \\
(19.3 \%)\end{array}$ & $\begin{array}{c}16 \\
(18.2 \%)\end{array}$ & $\begin{array}{c}21 \\
(23.9 \%)\end{array}$ & $\begin{array}{c}18 \\
(20.5 \%)\end{array}$ & $\begin{array}{c}16 \\
(18.2 \%)\end{array}$ & $88(100)$ \\
\hline $\begin{array}{l}\text { I receive all the support under } \\
\text { this governance system. }\end{array}$ & $\begin{array}{c}16 \\
(17.8 \%) \\
\end{array}$ & $\begin{array}{c}16 \\
(17.8 \%) \\
\end{array}$ & $\begin{array}{c}14 \\
(15.6 \%) \\
\end{array}$ & $\begin{array}{c}15 \\
(16.7 \%) \\
\end{array}$ & $\begin{array}{c}29 \\
(32.2 \%) \\
\end{array}$ & $90(100)$ \\
\hline $\begin{array}{l}\text { The communication system is } \\
\text { very confusing and unreliable. }\end{array}$ & $\begin{array}{c}14 \\
(15.1 \%) \\
\end{array}$ & $\begin{array}{c}19 \\
(20.4 \%) \\
\end{array}$ & $\begin{array}{c}24 \\
(25.8 \%) \\
\end{array}$ & $\begin{array}{c}19 \\
(20.4 \%) \\
\end{array}$ & $\begin{array}{c}17 \\
(18.3 \%) \\
\end{array}$ & $93(100)$ \\
\hline $\begin{array}{l}\text { The governance of teaching } \\
\text { and learning process is not } \\
\text { sustainable in this institution. }\end{array}$ & $\begin{array}{c}19 \\
(20.4 \%)\end{array}$ & $\begin{array}{c}12 \\
(12.9 \%)\end{array}$ & $\begin{array}{c}33 \\
(35.5 \%)\end{array}$ & $\begin{array}{c}14 \\
(15.1 \%)\end{array}$ & $\begin{array}{c}15 \\
(16.1 \%)\end{array}$ & $93(100)$ \\
\hline $\begin{array}{l}\text { The language policy is a } \\
\text { challenge to corporate } \\
\text { governance sustainability in the } \\
\text { institution. }\end{array}$ & $\begin{array}{c}17 \\
(18.5 \%)\end{array}$ & $\begin{array}{c}14 \\
(15.2 \%)\end{array}$ & $\begin{array}{c}26 \\
(28.3 \%)\end{array}$ & $\begin{array}{c}20 \\
(21.7 \%)\end{array}$ & $\begin{array}{c}15 \\
(16.3 \%)\end{array}$ & $92(100)$ \\
\hline
\end{tabular}

Table 4 presents the responses to the questions relating to the challenges and opportunities to sustainable corporate governance in the respondents' institution. Accordingly, 49.1 per cent $(16.9 \%$ and $32.2 \%)$ agree that the language culture of the institution is a hindrance to effective governance; 46.2 per cent $(20.4 \%$ and $25.8 \%)$ do not belief that the current governance system is well sustained; 41.9 per cent (19.8\% and $22.1 \%)$ have confidence in the current governance system of the institution; 42.1 per cent (18.2\% and 23.9\%) agree that they consider the corporate governance system as pro-active and very responsive; 33.4 per cent (17.8\% and $15.6 \%)$ agree that they receive all the support under this governance system; 46.2 per cent ( $20.4 \%$ and $25.8 \%$ ) agree that the communication system is very confusing and unreliable; 48.4 per cent $(12.9 \%$ and $35.5 \%$ ) agree that the governance of teaching and learning process is not sustainable in the institution; and lastly, 43.5 per cent $(15.2 \%$ and $28.3 \%)$ concur that the language policy is a challenge to corporate governance sustainability in the institution. Table 4 provides some insight into the fact that the institution's current governance system conveys mixed expectations and there is a strong indication (including the "not sure" respondents) that the current governance system has many challenges compared with the opportunities. The interviews also revealed that the institution despite being public and subsidised is still beset with decline financial support and increasing students need and demands such the free education and fees 
must fall (Hodes 2017, 145). The respondents also attributed the financial illiteracy on the part of student leaders as having bearing on sustainable implementation of corporate governance systems. It appears that almost all their demands and needs have financial implications and where it is not possible, they indulge in vandalism and burning of properties hence put strain on the sustainable implementation of the governance system (Langa et al. 2017, 83).

The board from campus management as well as senate and council members believe that the current governance system has many challenges from culture to social as well as the management practices (Hasan 2016, 320). Researchers on higher education institutions (Tshipa et al. 2018, 31) mention a number of features and characteristics of institutions of higher education universities that make them different from other kinds of organisations. These findings confirm that merged institutions are confronted with many opportunities and challenges which could derail or strengthen transformation. One respondent had this to say;

"Declining financial support from the fiscus; crisis of expectations with free education and fees must fall, financial illiteracy on part of student leaders all impact on governance system of the university"

Even though some interviewers mentioned that management has assisted so many students in financial distress, nevertheless there are students who fall out of this support net and those continue to pose a challenge to corporate governance in the sense that most strike emanate from these students who are outside the financial aid support. The following statements from two interviewers refer.

"Corporate governance does assist most students by getting them out of their outstanding debt/balance and also most of the students understand or were able to register for this academic year."

"Some of the students were not able to register for this current year so that they can further their studies and this is their only challenge."

\section{ESTABLISHING PERCEIVED CONFLICTS IN A NEW INSTITUTION OF HIGHER LEARNING}

The issue of inclusivity in corporate governance has been mentioned as element of perceived conflicts. Respondents felt that the institutional office which oversees the three campuses has become alienated from these campuses because decisions are finalised and implemented. Respondents feel that Campus A for instance does not have adequate representation of the various constituents of the institution and that their views and inputs are not considered and hence participative leadership is not practiced. A respondent had this to say: 
"Distances between three campuses and lack of trust among senior managers are evidence of perceived conflict."

"Management systems in institutions of higher learning are under pressure to manage their institutions along corporate lines or as business entities."

Below is how Participant D felt:

"Managing students and daily activities of the institution is a problem left unattended. The other thing is that management does not call students and hear out all the possible challenges which eventually cause the trouble."

"The governance of this institution does not always adhere to the needs of students and general stuff. As management you should know that we as students have needs."

"Given the fact that we are one university that is managed overall by the Institutional Office, it sometimes feels like the Potch campus is favoured more than the other two Campuses and that campus gets priority with regard to a number of things, such as programmes as well as the allocation of resources in general." (Participant M).

The study also found out that there is not much communication between certain stakeholders. For instance, student felt that management do not communicate with them as regularly as they would prefer. Hence, they resort to violence and vandalism as their expression of lack of attention from the university governing system. This sentiment was expressed by the interviewers as;

"Poor communication between the students and management. There is lack of access to information on rules, regulation and policies that govern the institution." (Participant D).

However, the university has developed several policies both for all stakeholders but it appears that many of these policies just remain on line and have not been accessed by the stakeholders.

The University restructuring also generated lots of uncertainty and conflict between management and staff to the extent that Management summoned relevant stakeholders to be briefed, just after the meeting staff and students could not reach a common understanding of the restructuring processes. Recently the Management issued a memorandum to assure all staff that there is no impending retrenchment possibilities within the new structure. The interviews however revealed the implications of the restructuring is still a perceived conflict between the governing body and the staff and students. This is what some interviewers had to say: "Since 2015-2017, there is growing uncertainty with respect to the implications of new structure". 


\section{CONCLUSION}

In conclusion, the data clearly illustrates that the respondents, both from the questionnaire and the interviews, were divided on factors influencing corporate governance systems implementation in institutions of Higher Learning product of a merger. Even though there were positive aspects of the current governance system, nevertheless the pendulum swayed towards the majority who felt that the governance system in place was not responsive enough and does not communicate as well as embrace all stakeholders. The study established that the university transformative process should ensure that all stakeholders are brought on board and made representative of gender, culture, social, language, race as part of the factors which promote sustainability of the corporate governance of the merged institution.

\section{RECOMMENDATION}

The study established that the communication processes and structures within the university require improvement especially with respect to students and staff administrative systems. The institution requires a sustained and realistic transformation agenda. This agenda should be accessible and understandable. Workshops on this agenda should be conducted continuously using understandable language and appropriate resourceful personnel taking into consideration the race and location as well as bottom up driven venture and not top down.

\section{REFERENCES}

Adams, Donald K. 2002. Education and national development: Priorities, policies, and planning. Manila Philippine: Asian Development Bank.

Asiedu, Michael Amoh, Emma Yalley, Kwame Owusu Boakye, Richard Oduro, and Isaac Nyarko Adu. 2020. "Corporate social responsibility and financial performance amongst rural and community banks in Ghana." Journal of Economics and Business 3(3).

Baird, Kevin. 2007. "Adoption of activity management practices in public sector organizations." Accounting \& Finance 47(4): 551-569.

Berle, A. A., and G. C. Means. 1932. The modern corporation and private property. New York, World.

Birnbaum, Robert. 1992. How academic leadership works: Understanding success and failure in the college presidency. Jossey-Bass Inc., 350 Sansome Street, San Francisco, CA 94104.

Bricall, Josep, and Fabio Roversi-Monaco. 2008. From the origins of the university in Europe to the universities of the globalisation. In Past, present and future of the Magna Charta Universitatum: Celebrations of the XX Anniversary of the Magna Charta Universitatum. Proceeding of the Conference of the Magna Charta Observatory, 18-20.

Cheng, Ming. 2016. Quality in higher education: Developing a virtue of professional practice. Springer.

Chinamal Anjeelee. 2019. "Corporate governance: Driving growth in Africa." https://www.ocorian. com/article/corporate-governance-driving-growth-africa. April 17. (Accessed 17 July 2020).

Coase, Ronald Harry. 1995. "The nature of the firm." In Essential readings in economics, 37-54. Palgrave, London,

Creswell, John W. 2011. "Controversies in mixed methods research.” The Sage handbook of qualitative 
research 4: 269-284.

DBET see Department of Basic Education and Higher Education and Training.

Department of Basic Education and Higher Education and Training. 2011. Integrated strategic planning framework for teacher education and development in South Africa: 2011-2025.

Dugan, Michael T., and Gary Taylor. 2016 "Ethical issues related to earnings management: An instructional case." Journal of the International Academy for Case Studies 22(3): 84-89.

Du Toit, André. 2014. Revisiting co-operative governance in higher education. A discussion document. Pretoria: HESA.

Elahi, Khandakar Qudrat-I. 2009. "UNDP on good governance.” International Journal of Social Economics 36(12): 1167-1180.

Fourie, Magda. 1999. "Institutional transformation at South African universities: Implications for academic staff." Higher Education 38(3): 275-290.

Fraenkel, Jack R., and Norman E. Wallen. 2012. How to design and evaluate research in education. Highstown, NJ: McGraw Hill Publishing Co.

Hall, Martin, Ashley Symes, and Thierry M. Luescher 2002. Governance in South African Higher Education. Research Report. http://www.che.org.za/documents/d000006/Governance Research_Report.pdf.

Hasan, Md Nazmul. 2016. Positivism: To what extent does it aid our understanding of the contemporary social world? Quality \& Quantity 50(1): 317-325.

Hodes, Rebecca. 2017. "Questioning 'fees must fall'.” African Affairs 116(462): 140-150.

Jarrar, Yasar, and Giovanni Schiuma. 2007. "Measuring performance in the public sector: Challenges and trends." Measuring Business Excellence 11(4): 4-8.

Kogan, Maurice. 2005. Governing knowledge: A study of continuity and change in higher educationA Festschrift in honour of Maurice Kogan. Vol. 9. Springer Science \& Business Media.

Langa, Malose, Sandile Ndelu, Yingi Edwin, and Marcia Vilakazi. 2017. \#Hashtag: An analysis of the \#FeesMustFall movement at South African universities. Centre for the Study of Violence and Reconciliation (CSVR), Johannesburg, South Africa.

Lukyanova, Natalya, Yury Daneykin, and Natalia Daneikina. 2015. Communicative competence management approaches in higher education. Procedia-Social and Behavioral Sciences 214: 565570.

Melese, Francois, James Blandin, and Sean OKeefe. 2004. A new management model for government: Integrating activity-based costing, the balanced scorecard, and total quality management with the planning, programming and budgeting system. International Public Management Review 5(2): $103-131$.

Mohamed, N., and N. Cloete. 1996. "Transformation forums as revolutionary councils, midwives to democracy or forums for reconstruction and innovation." Unpublished research report.

Neuman, Susan B. 2006. "How we neglect knowledge-and why." American Educator 30(1): 24.

Okeahalam, Charles C. 2004. Corporate governance and disclosure in Africa: Issues and challenges. Journal of Financial Regulation and compliance 12(4): 359-370.

O'Reilly, Michelle, and Nikki Kiyimba. 2015. Advanced qualitative research: A guide to using theory. Sage.

Ramsden, Paul. 1998. "Managing the effective university." Higher Education Research and Development 17(3): 347-370.

Republic of South Africa. 1997. The Higher Education Act. Act 101 of 1997.

Republic of South Africa. 2012. Act no 23 of 2012. Higher Education and Training Laws Amendment Act 2012. Gazette no. 36022. CAPE TOWN.

Roberts, Des. 2006. Governance in Higher Education in South Africa: A transformation and 
development perspective. http://pcf4.dec.uwi.edu/viewpaper.php?id=74. (Accessed 20 September 2020).

Rodriguez-Fernandez, Mercedes. 2016. "Social responsibility and financial performance: The role of good corporate governance.” BRQ Business Research Quarterly 19(2): 137-151.

Rwegasira, Kami. 2000. "Corporate governance in emerging capital markets: Whither Africa?" Corporate Governance: An International Review 8(3): 258-267.

Shi, Wei, Brian L. Connelly, and Robert E. Hoskisson. 2017. "External corporate governance and financial fraud: Cognitive evaluation theory insights on agency theory prescriptions." Strategic Management Journal 38(6): 1268-1286.

Solomon, J. F., and A. Solomon. 2006. "Private social, ethical and environmental disclosure." Accounting, Auditing \& Accountability Journal 19(4): 564-591.

Tricker, R. I. Bob, and Robert Ian Tricker. 2015. "Corporate governance: Principles, policies, and practices." Oxford University Press, USA.

Tsamenyi, Mathew, Elsie Enninful-Adu, and Joseph Onumah. 2007. "Disclosure and corporate governance in developing countries: Evidence from Ghana." Managerial Auditing Journal 22(3): 319-334. https://doi.org/10.1108/02686900710733170.

Tshipa, Jonty, Leon Brümmer, Hendrik Wolmarans, and Elda du Toit. 2018. "Corporate governance and financial performance in the midst of exogenous shocks: A study of companies listed on the Johannesburg Stock Exchange.” Management Dynamics: Journal of the Southern African Institute for Management Scientists 27(1): 20-38.

Van Den Bor, Wout, and James C. M. Shute. 1991. "Higher education in the third world: Status symbol or instrument for development?" Higher Education 22(1): 1-15.

Yakasai, Alhaji G. A. 2001. "Corporate governance in a third world country with particular reference to Nigeria.” Corporate Governance: An International Review 9(3): 238-253. 